2015

\title{
Legal Realism and Natural Law
}

Dan Priel

Osgoode Hall Law School of York University, dpriel@osgoode.yorku.ca

Charles L. Barzun

Follow this and additional works at: http:// digitalcommons.osgoode.yorku.ca/olsrps

\section{Recommended Citation}

Priel, Dan and Barzun, Charles L., "Legal Realism and Natural Law" (2015). Osgoode Legal Studies Research Paper Series. 92. http://digitalcommons.osgoode.yorku.ca/olsrps/92 


\section{OSGOODE HALL LAW SCHOOL LEGAL STUDIES RESEARCH PAPER SERIES}

\section{Research Paper No. 14}

Vol. 11/ Issue. 03/ (2015)

\section{Legal Realism and Natural Law}

Bazun, C. \& Priel, D. (in press). Legal realism and natural law. In M. Del Mar \& M. Lobban (Eds.) Law, theory and history: new essays on a neglected topic.

\section{Dan Priel \& Charlez Bazun}

\section{Editors:}

Editor-in-Chief: Carys J. Craig (Associate Dean of Research \& Institutional Relations and Associate Professor, Osgoode Hall Law School, York University, Toronto)

Production Editor: James Singh (Osgoode Hall Law School, York University, Toronto)

\footnotetext{
This paper can be downloaded free of charge from:

http://ssrn.com/abstract=2589584
}

Further information and a collection of publications from the Osgoode Hall Law School Legal Studies Research Paper Series can be found at: 
Osgoode Legal Studies Research Paper No. 14

Vol. 11/ Issue. 03/ (2015)

\title{
Legal Realism and Natural Law
}

Bazun, C. \& Priel, D. (in press). Legal realism and natural law. In M. Del Mar \& M. Lobban (Eds.) Law, theory and history: new essays on a neglected topic.

Dan Priel \& Charlez Bazun

\begin{abstract}
:
The possibility of any meaningful relationship between the legal realists and natural law looks at first rather far-fetched. When it first appeared on the jurisprudential scene, legal realism was savagely attacked by proponents of natural law theory. To this day legal realism is depicted as a modernist, critical, at times almost nihilist approach to law, the polar opposite of the ancient natural law theory that traces its roots to Greek and Roman philosophy, and insists on unchanging objective values. And yet, two of the most famous legal realists, Karl Llewellyn and Jerome Frank, expressed in some of their writings more than a passing endorsement of natural law theory. The purpose of this essay is to try and explain this seemingly odd aspect of their work and in this way help in reassessing their work. We do so by explaining how they understood natural law and how they incorporated it in their work. Though they did not understand the term in precisely the same way, for both of them natural law was connected to the values of the community, which both of them thought were central to understanding law, for explaining how it could remain relatively certain, and ultimately, how it derived its authority.
\end{abstract}

\section{Keywords:}

Legal realism, natural law, Karl Llewellyn, Jerome Frank, jurisprudence

\author{
Author(s): \\ Dan Priel \\ Associate Professor \\ Osgoode Hall Law School \\ York University, Toronto \\ E: dpriel@osgoode.yorku.ca
}

Charlez Bazun

Associate Professor

University of Virginia School of Law

E: cbarzun@virginia.edu 


\title{
LEGAL REALISM AND NATURAL LAW
}

\author{
Dan Priel and Charles Barzun* \\ Forthcoming in Law, Theory and History: New Essays on a Neglected Topic \\ (Maksymilian Del Mar \& Michael Lobban eds., forthcoming 20I 5).
}

\begin{abstract}
The possibility of any meaningful relationship between the legal realists and natural law looks at first rather far-fetched. When it first appeared on the jurisprudential scene, legal realism was savagely attacked by proponents of natural law theory. To this day legal realism is depicted as a modernist, critical, at times almost nihilist approach to law, the polar opposite of the ancient natural law theory that traces its roots to Greek and Roman philosophy, and insists on unchanging objective values. And yet, two of the most famous legal realists, Karl Llewellyn and Jerome Frank, expressed in some of their writings more than a passing endorsement of natural law theory. The purpose of this essay is to try and explain this seemingly odd aspect of their work and in this way help in reassessing their work. We do so by explaining how they understood natural law and how they incorporated it in their work. Though they did not understand the term in precisely the same way, for both of them natural law was connected to the values of the community, which both of them thought were central to understanding law, for explaining how it could remain relatively certain, and ultimately, how it derived its authority.
\end{abstract}

\section{INTRODUCTION}

Legal realism and natural law? The very juxtaposition sounds odd. In popular academic imagination natural law is all about eternal principles discoverable by pure reason, while legal realism is all about 'law in flux'. ${ }^{1}$ Natural law is the legal theory of Aristotle, Cicero, and Aquinas, whereas legal realism has variously associated with American pragmatism, logical positivism, behaviourism, psychoanalysis, modern anthropology, even quantum mechanics—all ideas firmly embedded in the twentiethcentury psyche. It is the association with these ideas that has led one commentator to say that "with its emphasis on empirical and functional methodologies and its thoroughgoing skepticism about moral or epistemological absolutes, [legal realism] would

"Associate Professor, Osgoode Hall Law School, York University and Professor, University of Virginia School of Law.

${ }^{1}$ See Karl N. Llewellyn, 'Some Realism about Realism-Responding to Dean Pound' (I93 I) 44 Harvard Law Review I 222 , 236. 
seem to be a quintessentially modernist jurisprudence'. ${ }^{2}$ What could such an approach have in common with the most un-modernist of legal theories, an approach that more than any other is associated with moral and epistemological absolutes?

The apparent disparity is not merely a matter of competing philosophies; it is part of history. When the realists came to prominence in the I930s, their fiercest critics were Catholic scholars, who often contrasted legal realism with natural law. One of them wrote that, 'Realism by taking God, soul, mind, will, innate dignity, and innate de jure independence away from man, makes man the pawn of might, and breaks the neck of democracy. Godless Behaviorism and Pragmatism are the head hunters, with Democracy and popular sovereignty the victims'. He associated legal realism with fascism and declared that in the battle of the day 'Democracy versus the Absolute State means Natural Law versus Realism'. ${ }^{4}$

Moving to the present, the gulf between legal realism and natural law still appears vast. Especially in the American context, natural law is these days typically invoked in defence of conservative causes $;^{5}$ by contrast, the realists' most immediate association is with the New Deal, a political agenda that to this day remains an anathema to many on the American right. The association of legal realism with natural law theory will also sound odd to those versed in contemporary debates in legal theory. Those who see the realists as early precursors of the critical legal studies movement will agree with Joseph William Singer that the 'legal realists removed the possibility of answering...questions [like how we come to our normative commitments and how we should question them] by appeal to natural law or to the logical implications of abstract concepts'. ${ }^{6}$ Finally, even among the narrower confines of analytic jurisprudence the association of legal realism with natural law flies in the face of an influential recent interpretation of legal realism according to which legal realism presupposes the truth of 'hard' legal positivism. ${ }^{7}$ This reading places legal realism as the polar jurisprudential opposite of natural law theory.

\footnotetext{
2 G. Edward White, 'Recapturing New Deal Lawyers' (I988) io2 Harvard Law Review 489, 5 I 4.

${ }^{3}$ See, e.g., Francis E. Lucey, 'Natural Law and American Legal Realism: Their Respective Contribution to a Theory of Law in a Democratic Society' (I942) 30 Georgetown Law Journal 493, 526, 53 I-32. Many additional examples are cited in Edward A. Purcell, Jr., The Crisis of Democratic Theory: Scientific Naturalism \& the Problem of Value (Lexington: University of Kentucky Press, I973) I60-72; Neil Duxbury, 'The Reinvention of American Legal Realism' (1992) i 2 Legal Studies I37, I64-73.

${ }^{4}$ Lucey (n 3) 533; to the same effect see Palmer (n 3) 62-63; cf Roscoe Pound, 'The Revival of Natural Law' (1942) I 7 Notre Dame Lawyer 287, 3 I 5, 32 2-2 3, 325.

5 See, e.g., Molly Worthen, 'The First Principles of Rick Santorum', New York Times (9 February 2OI2), available at http://campaignstops.blogs.nytimes.com/2OI2/o2/og/the-first-principles-of-ricksantorum/.

${ }^{6}$ Joseph William Singer, 'Legal Realism Now' (i 988) 76 California Law Review 465, 54I.

${ }^{7}$ See Brian Leiter, Naturalizing Jurisprudence: Essays on American Legal Realism and Naturalism in Legal Philosophy (Oxford: Oxford University Press, 2007) 73, I34-35. For critiques of Leiter's position (in-
} 
And yet, when one looks at the works of the people who called themselves 'legal realists', matters look less clear cut. Hessel Yntema stated that 'the classification of American legal realism in the category of positivism along with Austin, Kelsen, etc., is so superficial as to border on the perverse'. ${ }^{8}$ This does not yet show that the realists saw themselves as natural lawyers-after all, they might have seen themselves as a new kind of approach to law-but it already somewhat destabilizes the association between realism and positivism. Even more surprisingly, when one turns to the works of the two most famous legal realists one finds in them clear affirmations of a positive connection between legal realism and natural law. As early as I938 Karl Llewellyn wrote that 'it is difficult for me to conceive of the ultimate legal ideals of any of the writers who have been called realists in terms which do not resemble amazingly the type and even the content of the principles of a philosopher's Natural Law'. ${ }^{9}$ Even more surprisingly, Jerome Frank, usually considered among the most extreme realists, the one realists whose views are sometimes thought to border on nihilism, ${ }^{10}$ stated: 'I do not understand how any decent man today can refuse to adopt, as a basis of modern civilization, the fundamental principles of Natural Law. ${ }^{11}$ As these words do not fit the image Frank as the 'bad boy' of legal realism, they are not often discussed. When they are, they are explained away as reflecting the views of the 'later', mellower Frank (by then a federal appellate judge), troubled by the horrors of World War II. ${ }^{12}$

We will address this claim in more detail below, but already here we will note some difficulties with it. In the same year Frank wrote the words just quoted, he published Courts on Trial, which is hardly a complacent look at the legal system. On the other hand, already in 1932 Frank forcefully denied that the realists are "positivists" who are exclusively devoted to whatever is now happening in the legal world'. The realists, he said, were all 'eager...to improve the judicial system, to make it more efficient, more responsive to social needs, more "just", if you like that word'. ${ }^{13}$

dependent of the arguments developed here) see Danny Priel, 'Were the Legal Realists Legal Positivists' (2008) 27 Law and Philosophy 309; Dan Priel, 'Jurisprudence between Science and the Humanities' (201 2) 4 Washington University furisprudence Review 269, 307-3 г 6.

${ }^{8}$ Hessel Yntema, 'Jurisprudence on Parade' (I94I) 39 Michigan Law Review I I 54, I I64.

9 Karl N. Llewellyn, 'One "Realist's" View of Natural Law for Judges' (I939) I 5 Notre Dame Lawyer 3,8 .

${ }^{10}$ See, e.g., H.L.A. Hart, 'American Jurisprudence through English Eyes: The Nightmare and the Noble Dream' (1977) I I Georgia Law Review 969, 974; Leslie Pickering Francis, 'Law and Philosophy: From Skepticism to Value Theory' (1993) 27 Loyola of Los Angeles Law Review 65, 73.

${ }^{11}$ Jerome Frank, Law and the Modern Mind, 6th printing (Garden City: Anchor Books, I949) xx.

12 Perhaps the first to make this claim is Malcolm P. Sharp, 'Realism and Natural Law' (I957) 24 University of Chicago Law Review 648, 655-57.

${ }^{13}$ Jerome Frank, 'Mr. Justice Holmes and Non-Euclidean Legal Thinking' (1932) i 7 Cornell Law Quarterly 568, 586. 
One aim of this essay is therefore to make sense of these seemingly odd statements. We will argue below that rather than suggesting a radical change in the views of Llewellyn and Frank, they reflect ideas that can be found in even in their earliest, and seemingly most critical, works. Before we proceed, however, we must add an important caveat. While Llewellyn and Frank were in their day, and remain to this day, among the best-known legal realists, we do not claim that they are necessarily representative of all legal realists, let alone of some abstract construct called 'legal realism'. Both Llewellyn and Frank often warned against the 'Schools' approach to jurisprudence for its tendency to lump together different thinkers who are in fact quite different. ${ }^{14}$ Indeed, what we say below is not meant to deny that some self-described legal realists expressed scepticism about natural law ideas. ${ }^{15}$ And as our argument unfolds, it will become apparent that even Llewellyn and Frank understood the term somewhat differently. One incidental aim of this essay is thus to serve as reminder that all attempts to identify what legal realism is should be treated carefully. Such efforts are often illuminating, but they must be understood as constructs of the views of numerous individuals who on many things held quite different views. In this essay we therefore limit our focus to an analysis of the views of two legal realists.

One stumbling block to any meaningful discussion of the question any possible relationship between legal realism and natural law requires some clarification of the possible senses in which Llewellyn and Frank thought of themselves as natural lawyers and (if this is any different) opponents of positivism. In so doing, we must begin by setting aside several possible interpretations of these terms as inadequate. To begin, neither Frank nor Llewellyn believed that consistency with true morality was a condition of legal validity (or, more colloquially, that an unjust law was not valid law). From the vantage point of contemporary jurisprudence, this may seem odd, as the divide between legal positivism and anti-positivism is often defined in terms of legal validity. But from a historical perspective, the absence of a discussion on the matter of legal validity is unremarkable. If one looks at the long history of natural law thinking, one finds the conditions of legal validity rarely discussed. In fact, in English one is hard-pressed to find any discussions that pit legal positivism against natural law before I93 ${ }^{16}{ }^{16}$ Even today, some natural lawyers deny that 'natural law theory' is committed

${ }^{14}$ K.N. Llewellyn, Law in Our Society: A Horse-Sense Theory of the Institution of Law (unpublished course materials, I950 edition) 82-83; see also Jerome Frank, If Men Were Angels: Some Aspects of Government in a Democracy (New York: Harper, I942) 277-79.

${ }^{15}$ See Walter W. Cook, 'Scientific Method and the Law' (1927) I3 American Bar Association Fournal 303, 306; Joseph Walter Bingham, 'Law Schools and the Future' (1954) 6 Journal of Legal Education 486, 496-97 note 3; Oliver Wendell Holmes, 'Natural Law' (i918) 32 Harvard Law Review 40.

${ }_{16}$ The very contrast between natural law and legal positivism, as two opposing jurisprudential schools is of a much more recent provenance than is often assumed. In Germany it begins to appear in the late nineteenth century and in France some years later. In English-speaking world one begins to see 
the view that an unjust law is not law. ${ }^{17}$ Since many prominent natural lawyers profess a decided lack of interest in the question of legal validity and are willing to countenance the possibility of unjust laws, the absence of a discussion of this question in Llewellyn and Frank's works does not undermine our suggestion that they endorsed versions of natural law.

After setting aside such questions, is there any remaining interesting connection between legal realism and natural law? Even if so, is the connection of more than antiquarian interest today? ${ }^{18}$ Our answer is, Yes and yes. First, by appealing to natural law Frank and Llewellyn both signalled their commitment to the reality of value and the possibility of reasoning about it. Even if they could not come to accept everything carried under the banner of natural law, they maintained a faith in some notion (however vaguely specified) of moral reality. Second, Llewellyn and Frank believed that one could not clearly distinguish between legal and other sorts of norms, whether moral, social, or political. And third, Llewellyn and Frank saw their views about law and jurisprudence as closely related to inquiries about politics, and especially American politics. More specifically, their account of law was an account of American law, which they presented as intimately tied to American democracy, both of which they explicitly connected to natural law.

Not every legal positivist will disagree with all three points; the third one in particular is these days accepted by many legal positivists. But taken together, these three points represent a position clearly at odds with the views of many twentieth century and contemporary legal positivists, including the most prominent Anglophone legal positivist, H.L.A. Hart. ${ }^{19}$ Indeed, on all three counts Llewellyn and Frank can count as allies Hart's primary anti-positivist antagonists, Lon Fuller and Ronald Dworkin, both of whom, at least on occasion, associated themselves with natural law. ${ }^{20}$

it only in the I930s in writings of scholars well-versed in European jurisprudence. See e.g., K.N. Llewellyn, 'On Philosophy in American Law' (1934) 82 University of Pennsylvania Law Review 205, 206-08; Lon L. Fuller, The Law in Quest of Itself (Chicago: Foundation Press, I940) 4-6. At the time the debate is not treated exclusively (or even primarily) as a debate about legal validity.

${ }^{17}$ See John Finnis, Natural Law and Natural Rights, 2nd ed. (Oxford: Oxford University Press, 20 I I) 363-66. Even those who do think that natural law theory entails the idea that unjust law is not law think this is only a small component of natural law theory.

${ }^{18}$ We explore (but don't resolve) some of the issues arising more general questions arising from alluded to in the text in Charles Barzun \& Dan Priel, 'Jurisprudence and (Its) History' (2015) Ior Virginia Law Review (forthcoming).

${ }^{19}$ As a moral sceptic (of sorts) Hart may well have disagreed with all three. And he is not alone. Other prominent legal positivists whose legal positivism may be related to a version of moral anti-realism include Hans Kelsen, Jules Coleman, and Brian Leiter.

${ }^{20}$ See Lon L. Fuller, 'Human Purpose and Natural Law' (I945) 53 Fournal of Philosophy 697. Dworkin was used the term less frequently, but at least once he defined and endorsed natural law as the view that 'insists that what the law is depends in some way on what the law ought to be'. See Ronald 


\section{Karl Llewellyn: The Romantic NatUral Lawyer}

In Hart's famous characterization, American jurisprudence swerves between two extremes he dubbed the nightmare and the noble dream, extreme scepticism of the law on the one hand, and unbridled faith in it on the other. And though Hart stated that the nightmare view is most associated with legal realism, ${ }^{21}$ in that essay he recognized (in a way he did not recognize before) that at least as far as Karl Llewellyn was concerned, the picture was more complex. ${ }^{22}$ The truth is that the more one reads Llewellyn, the more difficult it becomes to imagine a more enthusiastic noble dreamer of the law. Rather than a sceptic, Llewellyn was the law's greatest romantic. ${ }^{23}$

The following words give a sense of Llewellyn's romanticism: ${ }^{24}$

There is the man who loves creativeness, who can without loss of sleep combine risktaking with responsibility, who sees and feels institutions as things built and to be built to serve functions, and who sees the functions as vital and law as a tool to be eternally reoriented to justice and to general welfare. There is the other man who loves order, who finds risk uncomfortable and has seen so much irresponsible or unwise innovation that responsibility to him means caution, who sees and feels institutions as the tested, slow-built ways which for all their faults are man's sole safeguard against relapse into barbarism, and who regards reorientation of the law in our polity as essentially committed to the legislature..$^{25}$

This embrace of the virtues of uncertainty did not imply chaos. As early as in a book published in 1933 (based on lectures delivered in 1928-29) Llewellyn wrote that "'free law" is free only within this small space, and in no way threatens a true legal certainty'. ${ }^{26}$ At the same time, what stopped the law from calcifying was '[t]he quest of

Dworkin, “"Natural” Law Revisited' (I982) 34 University of Florida Law Review I65, I65. The similarity between this view and Fuller's is unmistakable.

${ }^{21}$ Hart (n Io) 974.

22 See his reference to Llewellyn in ibid. 978-79.

${ }^{23}$ For a sense of Llewellyn's romanticism see N.E.H. Hull, 'The Romantic Realist: Art, Literature and the Enduring Legacy of Karl Llewellyn's "Jurisprudence" (I996) 40 American fournal of Legal History I I 5, esp. I I 7-23, I40-45; William Twining, Karl Llewellyn and the Realist Movement, 2nd ed. (Cambridge: Cambridge University Press, 20 I 2) i I 7-2 3, I 43-44.

${ }^{24}$ This is romanticism of the moderns. See Jackson Lears, Something for Nothing: Luck in America (New York: Penguin, 2003) 28 I-82, 284-85.

${ }^{25}$ Karl N. Llewellyn, 'Remarks on the Theory of Appellate Decision and the Rules or Canons about How Statutes Are to Be Construed' (I950) 3 Vanderbilt Law Review 395, 397. As we will show below, Frank held a similar view. And other realists held the same view. See William O. Douglas, 'The Dissent: A Safeguard of Democracy' (1948) 32 Fournal of the American Fudicature Society 104, I05 (those who believe in the 'democratic faith will rejoice in the uncertainty of law and find strength and glory in it'); Max Radin, in My Philosophy of Law: Credos of Sixteen American Scholars (Boston: Boston Law Book, I94I) 287 , 293 (talking of 'the glorious uncertainty of the law').

${ }^{26}$ Karl Llewellyn, The Case Law System in America, Paul Gewirtz ed., Michael Ansaldi trans. (Chicago: University of Chicago Press, I989 [I933]) 78. Llewellyn alludes here to the German jurisprudential 
Right Goals [which]...is...an inherent part of any healthy institution of law: a vital part'. ${ }^{27}$

The quest of Right Goals and its role in any healthy institution of law points towards the sense Llewellyn saw himself as a natural lawyer. On its own, however, it establishes only a superficial link with natural law thinking. Moreover, like many enthusiasts for the common law before and after him, Llewellyn was wary of philosophical abstractions, and therefore had another reason to be wary of appeals to natural law. He worried that many natural lawyers committed 'the error' of going on a quest that 'carries the quester into the realm of untestable truth'.$^{28}$ It was tempting but dangerous for the committed natural lawyer to end up with nothing but 'a fighting faith, explored and buttressed by his reason, but necessarily inconclusive on the level of testable truth'. ${ }^{29}$ Llewellyn therefore distanced himself from the view that judges should turn to their understanding of what right reason required in their quest for identifying the law. ${ }^{30}$

But if natural law was neither abstract reason nor the judge's own reason, what was it and where did come from? In an early discussion Llewellyn stated tentatively that 'it is to law that we owe the conception of justice', it is the law's 'own perfection', ${ }^{31}$ and that it is this idea that provides the main limit and constraint on the judge. ${ }^{32}$ This statement reflects a fairly familiar idea of the common law as a basis for its own improvement. This is the idea that sees the common law as a practice that 'works itself pure', by reworking and refining disparate decisions into a coherent set of principles. A few years later, when Llewellyn began to make more open references

'free law' movement. It has been forcefully argued that the free law movement has been an intellectual source for American legal realism. See James E. Herget \& Stephen Wallace, 'The German Free Law Movement as the Source of American Legal Realism' (1987) 73 Virginia Law Review 399. While we do not deny that there are important similarities between the writers in of the two 'schools', it is notable that Llewellyn was fairly critical of free law. After stating that the judge's 'freedom of movement' is only within 'a small space', he added that ' $[t]$ he only noteworthy contribution of the "free law" movement is...to advocate that [the] freedom of movement be consciously understood and not exercised blindly'. Llewellyn, ibid. As we will show below, Llewellyn had closer affinities to the German historical school, which was one of the free law scholars' targets.

${ }^{27}$ Llewellyn (n I4) 6o. Incidentally, it was because Kelsen ignored this aspect of law that Llewellyn thought his work was 'sterile'. Ibid.

${ }^{28} \mathrm{Ibid}$.

${ }^{29} \mathrm{Ibid}$.

${ }^{30}$ See also Karl N. Llewellyn, The Common Law Tradition: Deciding Appeals (Boston: Little, Brown, I960) 422 .

${ }^{31}$ K.N. Llewellyn, The Bramble Bush: Some Lectures on Law and Its Study (Columbia University, I930) I 2 I.

32 ' $[\mathrm{C}]$ ourts must move within the framework of the given rules. The rules, however socially unjust they seem to [any individual]....are there. The court is in part their mouthpiece. What it can do, all it can do, is to soften a little there and there in a detail the rigor of the general scheme'. Ibid, 8 o. 
to natural law, it becomes possible to identify a subtle but crucial shift in his view. Llewellyn began to distinguish between the 'philosopher's Natural Law' and that of the lawyer. ${ }^{33}$ The former, while significant is too abstract and general to be of much use for the practical needs of a lawyer who seeks fairly determinate solutions to legal problems. When the lawyer is concerned with natural law, by contrast, he is concerned with 'bis rules for bis society'. ${ }^{34}$ This is where the lawyer's natural law was far more significant. What was that? Llewellyn's new alternative to 'untestable truths' of the philosopher was no longer to quarry the law's own materials for answers. Instead, Llewellyn suggested that the source of law's improvement was the people. The more familiar natural law theories focus on 'Goals as the heart of Jurisprudence and on Right Reason as a method'; theories that focus on positive law and seek to find answers to novel problems there 'center on the prevailing Rules and Concepts of Law as the structured machinery without which nothing gets done and on formal logic as a method'. This approach, however, ignores '[t]he people whose law Law is and for whom Law is'. It is for this reason that for Llewellyn natural law 'bears a relation to positive law... which is curiously similar to the relation of such positive law to actually prevailing human behavior'. ${ }^{35}$ Modifying the familiar image of natural law as higher law, Llewellyn stated that '[i]f in one sense Official Law (and Natural Law) must be above the people to control them, in another sense it must be in and of them, or it ceases to be in society'. ${ }^{36}$

Thus, against the familiar image of natural law as a set of unshifting Archimedean points in a constantly changing world, Llewellyn offered a different conception of natural law as the basis for his risk-taking ideal for the law. Natural law thus stood for the essential vitality of law, for its openness to critique and change. The courts who adopted such an attitude, courts that worked in what Llewellyn called the 'grand style', often described their jurisprudence in terms of natural law: 'To me...the feature which they treat as "Natural Law" thinking has as its essence a conscious and sustained quest for and accounting to the best reason a court could find'. ${ }^{37}$

Llewellyn took to be the essence of his view the words he quoted from nineteenth century German commercial lawyer, Levin Goldschmidt:

Every fact-pattern of common life, so far as the legal order can take it in, carries within itself its appropriate, natural rules, its right law. This is a natural law which is real, not imaginary; it is not a creature of mere reason, but rests on the solid foundation of what reason can recognize in the nature of man and of the life conditions of the time and place; it is thus not eternal nor changeless nor everywhere the same, but is in-

\footnotetext{
${ }^{33}$ Llewellyn (n 9) 3-4.

${ }^{34} \mathrm{Ibid}, 4$ (emphasis in original).

${ }^{35}$ Ibid 5 .

${ }^{36}$ Llewellyn (n I4) 72; see also Llewellyn (n 9) 6.

${ }^{37}$ Llewellyn (n 30) 422 .
} 
dwelling in the very circumstances of life. The highest task of law-giving consists in uncovering and implementing this immanent law. ${ }^{38}$

As Llewellyn intensified his focus on prevailing norms among the people as the source for law's development, he was moved to suggest that even those who spoke of natural law in the sense of timeless, universal principles, were more often talking about what they were familiar with: ' $[W]$ hen the natural law philosopher proposes his ideal solutions', Llewellyn wrote, 'he again and again reverts to positive law of his homeland'. ${ }^{39}$ On another occasion he warned of the error he attributed to 'fourth-rate Natural Lawyers', the error of treating the conventions of their day as reflecting some self-evident reality. ${ }^{40}$

The standards by which laws are to be assessed, then, were not timeless: 'in regard to matters of change or crisis I am prepared to argue firmly that right timing... also becomes a vital aspect of the rightness... of the relevant portions of right-law [i.e., what law ought to be]'. ${ }^{41}$ This is because what the law ought to be, the idea that the law ought to pursue must be 'so built as to have heavy impact upon its own people, and so upon the people of some one particular time, place and cultural tradition'. ${ }^{42}$

Those who still find odd Llewellyn's suggestion that natural law was implicit in a society's norms and values might try to dismiss it as the product of an idiosyncratic definition of the latter term, which means almost the opposite of the prevailing understanding of the term. But this understanding was not an invention of Llewellyn's wild imagination. If one tries to find the intellectual sources on which Llewellyn drew for his views, there seem to be two main sources. One, already alluded to, is German romanticism and its legal counterpart, the historical school of jurisprudence and its interpretation of natural law. ${ }^{43}$ The other, no less important, is American ideas of selfgovernment and democracy, and their relationship to natural law. Llewellyn's embrace of natural law can thus be understood as an attempt to bring together these two

${ }^{38}$ Ibid, I 22. Of these words Llewellyn said: 'I doubt if the matter has ever been better put than that'. Ibid.

${ }^{39}$ Llewellyn (n 26) 77.

${ }^{40}$ Llewellyn (n I4) 4. Curiously, Llewellyn attributed this mistake to both the American Declaration of Independence and the Communist Manifesto. Ibid.

${ }^{41}$ Karl N. Llewellyn, 'What Law Cannot Do for Inter-Racial Peace' (I957) 3 Villanova Law Review 30, 3 I.

$42 \mathrm{Ibid}, 3 \mathrm{O}-3 \mathrm{I}$.

${ }^{43}$ This interpretation of natural law had already been described (in works familiar to Llewellyn) in Roscoe Pound, Interpretations of Legal History (New York: Macmillan, I923) I49-50; Roscoe Pound, Law and Morals (Chapel Hill: University of North Carolina Press, i924) I6-I9. On this aspect of Llewellyn's thought see James Whitman, 'Commercial Law and the American Volk: A Note on Llewellyn's German Sources for the Uniform Commercial Code' (1989) 97 Yale Law Journal I 56. 
strands of thought. Llewellyn did this through his interpretation of the 'common law tradition', especially in its American incarnation.

Llewellyn did this by connecting three ideas-historical jurisprudence, the common law, and democracy - to 'the people'. Llewellyn was not the first to draw a link between the first two, ${ }^{44}$ but more than those before him he drew an explicit connection between American common law and American democracy. In one of his discussions of his distinction between the 'formal' and 'grand' styles of adjudication he drew a contrast between a view that seeks to 'discipline society' and the view that seeks to 'follow society'. In this and other respects the formal style 'r[a]n counter' to various ideas 'gathered under the label of "democracy", 45 at least if democracy as understood, as it did for him, as an 'active participation of the beneficiaries' ${ }^{46}$ In a similar way he highlighted American common law's 'earthly rooting', its distributed nature among the different states, the fact that it was a law that 'voices...the residual non-expert horse-sense of the community'. ${ }^{47}$

The idea of self-government or popular sovereignty has been central to the American conception of democracy, and the debates on the structure of the American polity that accompanied the founding of the United States and the adoption of the federal Constitution can, in part, be understood as debates on the problem of reconciling ideas of natural law with ideas of self-government. ${ }^{48}$ Whether and how this is to be done has been the subject of numerous studies on the political ideas at the time of the founding of the American republic. For our purposes, what matters is the way Llewellyn blended these ideas to present what he thought was a distinctly American conception of the common law as an essential ingredient of American democracy.

Though not a matter on which Llewellyn wrote at great length, what he did write reveals a political theory of law, one that sees this societal natural law as imposing a constraint on judges and providing certainty to the law that legal texts on their were incapable of providing. It provided a political limit to legitimate (and perhaps also feasible) use of the law for the promotion of social change. At the same time, this is a vision of law that is fundamentally opposed to government that is 'secret, self-

\footnotetext{
${ }^{44}$ See Mathias Reimann, 'The Common Law Against Codification: Savigny, Carter, and the Defeat of the New York Civil Code' (1989) 37 American Journal of Comparative Law 95, 103-07.

${ }^{45}$ K.N. Llewellyn, 'American Common Law Tradition and American Democracy' (1942) I Fournal of Legal and Political Sociology $\mathbf{1}, 34$.

${ }^{46} \mathrm{Ibid}, 29$.

${ }^{47} \mathrm{Ibid}, 3 \mathrm{O}, 3 \mathrm{I}$.

48 There is potential tension between notions of natural law and popular sovereignty. For discussions of attempts to reconcile them see Ernest Barker, Traditions of Civility: Eight Essays (Cambridge: Cambridge University Press, I948) 3 I4-I 8; Tom N. McInnis, 'Natural Law and the Revolutionary State Constitutions' (1990) I4 Legal Studies Forum 35 I, 356-57.
} 
sufficient in judgment and standard, accounting neither to the individual for particular decision nor to the public for general policy'. ${ }^{49}$

All of this calls for some revision of the still-popular image of legal realism, or more accurately of Llewellyn's legal realism, and its place in the map of contemporary legal theory. Hart correctly recognized Llewellyn's views as fundamentally at odds with his, but his explanation of the difference was mistaken because he misunderstood Llewellyn's position. In The Concept of Law Hart treated Llewellyn (on the basis of a single sentence taken out of context) as a paradigmatic example of rule scepticism. ${ }^{50}$ But this is a mistake, since, as we have shown, Llewellyn never doubted that rules provided the law with considerable certainty. ${ }^{51}$ The difference between Llewellyn and Hart lies elsewhere. In Hart's view, the legal rules are capable of constraining because their verbal formulations apply clearly to some cases. ${ }^{52}$ For Hart (and many other legal positivists) these clear and uncontroversial applications of rules mark out the limits of law's domain. ${ }^{53}$ Hart did not think judges can never rely on moral considerations, but when they did so they were relying on moral or social considerations that stood outside the law. ${ }^{54}$

Llewellyn rejected all this. Law was largely certain, but not because deduction from legal rules provided certainty, and definitely not because there was a clearlydefined domain of law identified as the domain of posited legal rules. Law for him was largely certain precisely because law was more than legal rules. ${ }^{55}$ In contrast to the positivist picture, both the constraints that fix the content of the law, and the ideals that law should pursue, are part of the law. Thus, there are no clear boundaries between law and society, and between law and non-law. ${ }^{56}$ It is the process of socialization that

${ }^{49}$ Llewellyn (n 45) 42. Llewellyn attributed these features to the British style of government. Ibid. This makes for a parallel contrast between Llewellyn's view of American and British common law. See K.N. Llewellyn, 'On the Good, the True, the Beautiful, in Law' (1942) 9 University of Chicago Law Review $224,236-37$.

${ }^{50}$ See H.L.A. Hart, The Concept of Law, 3 rd ed. (Oxford: Oxford University Press, 201 2) I, I 39. Criticism of Hart's presentation of realists' ideas goes back at least as far as E. Hunter Taylor, Jr., 'H.L.A. Hart's Concept of Law in the Perspective of American Legal Realism' (1972) 35 Modern Law Review 606. But even critics of Hart's interpretation of legal realism typically associate legal realism with a form of rule scepticism. See Leiter (n 7) 73-78.

${ }^{51}$ See text accompanying note 26.

${ }^{52}$ Hart (n 50) I 26.

${ }^{53}$ This characterization of legal positivism as the thesis that 'there is a test which distinguishes what is law from what is not' is first articulated in Joseph Raz, 'Legal Principles and the Limits of Law' (I972) 8 I Yale Law Journal 823, 842; see also Frederick Schauer, 'The Limited Domain of the Law' (2004) 90 Virginia Law Review I 909.

${ }^{54}$ Hart (n 50) I 35 .

${ }^{55}$ See Llewellyn (n 26) i I-I 2, 78.

${ }^{56}$ Karl N. Llewellyn, 'How Appellate Courts Decide Cases' (1945) i6 Pennsylvania Bar Association Quarterly 220, 2 27; cf Llewellyn (n 49) 246, 248. 
provides the limiting constraints fixing the content of law, but also the law's ideals. Indeed, in this picture the distinction between the reality and ideal of the law becomes blurred. This, we think, is the deepest sense in which Llewellyn is an antipositivist and the sense in which he thought of himself as a natural lawyer. ${ }^{57}$

\section{Jerome Frank: Pragmatic SCholasticism}

There is admittedly something ironic about ascribing the label 'natural law' to any of Jerome Frank's views. The reason is that Frank himself often shunned the term, concluding it was too malleable and ambiguous to be of much use. Nevertheless, like Llewellyn, he endorsed philosophical views associated with both ancient and modern versions of natural law theory and expressed increasing sympathy for what he took to be its main principles. Frank's commitment to those principles, including his faith in the natural freedom and individual dignity of all humans, may seem at odds with the scepticism for which Frank is famous. ${ }^{58}$ For that reason, and as already noted, some have been tempted to write off the former set of views as the result of a postwar transformation of sorts, fuelled by a need to distance himself from legal-realist ideas linked by others to the rise of fascism and Nazism. But while it is true that Frank's discussions of natural law mostly occur in the I940s, we argue that both his faith and his scepticism stem from the same pragmatist philosophical outlook, which one finds in even his earliest writings.

There is no doubt that Frank had trouble with the term 'natural law'. In some of his later writings, he criticized it and called for its abandonment. ${ }^{59} \mathrm{He}$ said he found the term ambiguous, confusing, and susceptible to abuse. He wrote, for example, that even 'Nazidom has its ideals, its own vicious notions of "natural law" and justice'. 60 Closer to home, the language of natural law and natural rights had been used 'to sanctify the most deplorable consequences of the commercial revolution', by which

57 This interpretation places Llewellyn quite close to Fuller. This may seem odd, as one of Fuller's critiques of the realists was precisely their mistaken effort to keep is and ought strictly separate. See Fuller (n I6) 60, 64-65. It is true that in early writings, such as Llewellyn (n I) I 236-37, Llewellyn insisted on a 'temporary' separation between is and ought, but as Fuller recognized, Llewellyn seems to have moved away from this position in later writings, and indeed has even cited Fuller's book approvingly. See Fuller, ibid, 6r; Llewellyn (n 30) 42 I-22.

${ }^{58}$ Jerome Frank, Fate and Freedom: A Philosophy for Free Americans, rev. ed. (Boston: Beacon, I953) 2 I4 (praising the 'humanistic spirit of Erasmus and Thomas More, with its rejection of asceticism, its stress on the individual man's dignity and moral worth in this world, its ideal of developing the best of man's nature in a just society').

${ }^{59} \mathrm{Ibid}, 298$ (referring to natural law as a 'dangerously ambiguous terminology'); Biedler v. Bookmyer, (I943) I 34 F.2d 828, 830 note 7 (lamenting that 'most persons who are not students of Scholastic jurisprudence (and some who purport to be) give, other, and often conflicting, meanings to "Natural Law"').

${ }^{60}$ Jerome Frank, Book Review, (1944) 57 Harvard Law Review I I 20 , I 28. 
Frank referred to social Darwinism and economic laissez faire. ${ }^{61}$ But the concern was not just with terminology; Frank also objected to a particular form of argument that relied on natural law. Frank vehemently disagreed with the view that it is possible to derive any automatic prescription for human society from nature: 'Nature is no copybook containing precepts for civilized man. Nor is human nature, unartificilized, a sound foundation for a beneficent social structure'. ${ }^{2}$ Thus, Frank pleaded, '[i]t is high time...that we put an end to the process of referring to "nature" as the justification for any particular social program.... The honest approach is to say: "Here is my program. Whether or not it is 'right' depends upon whether it is in accord with, and will promote, values and ideals which you think both desirable and possible of achievement....". ${ }^{63}$

Frank identified another problem with the term. Throughout history it had become mixed up with the causal claim that laws of nature determined all events, including human behaviour. ${ }^{64}$ Thus, many exponents of natural law had been complicit in aiding and abetting what was, for Frank, the true philosophical foe, namely scientific determinism (or as he sometimes called it 'fatalism'). ${ }^{65}$

Frank's commitment to human free will is an important theme to which we will return, but it is worth first laying out why, despite his reservations about the terminology of natural law, Frank nonetheless embraced its central tenets. In his 1945 book, Fate and Freedom, Frank emphasized that the following ideas and beliefs were 'never more precious than today': 'the ideals of justice and equality, a high regard for non-material values', and 'a belief in the necessity of restraints on absolutism and arbitrariness in government'. ${ }^{66} \mathrm{He}$ then went on to say that '[n]o decent, intelligent American will disagree' with the repudiation of the idea that 'man's "free will is frozen into muscular behavior," or with a "belief in the brotherhood of man." ${ }^{67}$ Rather, most Americans, Frank explained, would accept the idea that there are such 'basic principles', which are 'derived from man's nature', and that positive law ought to re-

${ }^{61}$ Frank (n 58) I 34. Also ibid, I36 (“"Natural," to devotees of laissez faire, meant what they considered desirable'). For an example of a book presenting classical economics as natural law see Henry Wood, The Political Economy of Natural Law (Boston: Lee and Shepard, I 894).

${ }^{62}$ Frank (n 58) I 4 I.

${ }^{63} \mathrm{Ibid}, \mathrm{I} 39$.

${ }^{64} \mathrm{Ibid}$, I I 5 ('in early stages of Greek religion, the belief that fate, law, order, and justice operated throughout the universe represented a reflection of "primitive" ideals of human law, of moral obligations, of order and justice in human society').

${ }^{65} \mathrm{Ibid}$, at ${ }_{0}$ ('Scientific fatalism is but a faith, a dismal and cruel one. We need not accept it. There is no reason why we should forsake the American faith-which rests on the facts of daily experiencethat human purposes are real').

${ }^{66} \mathrm{Ibid}, 294$.

${ }^{67} \mathrm{Ibid}$. 
flect them. ${ }^{68}$ In a different essay from the same period he reiterated this view when he praised the 'Scholastic version of natural law [which] symbolizes a noble ideal of minimum human decencies' ${ }^{69}$

For Frank, Thomas Aquinas represented the best of the natural law tradition. 'Wise and, for his day, tolerant', Frank explained, 'St. Thomas taught that there are but a few, and highly general, immutable principles of natural law. Men should do good and avoid evil, good being what is good for man in the light of his "natural" inclinations'. ${ }^{70}$ There were also a few secondary principles, such as 'not to kill, not to steal, to return goods held in trust'. ${ }^{71}$ Most importantly, Aquinas understood that how these principles applied to actual human problems varied with time and place. Thus, the chief virtue of Aquinas's understanding of natural law was that it was 'exceedingly flexible and relatively undogmatic'. ${ }^{72}$ Moreover, Frank endorsed the views that such values as freedom, justice, and equality really exist, that one could reason about them, and that judges should make reference to such values when deciding cases. In that sense, then, it seems plausible to characterize Frank as a defender of natural law.

Or does it? Even if one acknowledges that Frank wrote such statements of support for these natural-law views, one might still object that they seem entirely ad hoc and thus insufficient to alter our overall impression of Frank's thought. More than Llewellyn, these views seem plainly inconsistent with the extreme scepticism about law and judicial decision-making that made Frank famous. ${ }^{73}$

One explanation for this apparent change in view is a historical one. Frank wrote Law and the Modern Mind in I930, when sceptical views about religion and morality were increasingly common among social scientists and intellectuals in the United States. ${ }^{74}$ But by the time Frank was writing Fate and Freedom, the Allies were engaged in a world war against fascist and Nazi regimes, and the legal realists with whom Frank had been associated, had been attacked for endorsing views that gave philosophical support to such regimes. Thus, some have suggested that Frank's volte face

${ }^{68} \mathrm{Ibid} 295$.

${ }^{69}$ See Jerome Frank, 'A Sketch of an Influence' in Paul Sayre (ed), Interpretations of Modern Legal Philosophies: Essays in Honor of Roscoe Pound (New York: Oxford University Press, 1947) I89, 234.

${ }^{70}$ Frank (n 58$)$ I 23.

${ }^{71} \mathrm{Ibid}, \mathrm{I} 24$.

${ }^{72} \mathrm{Ibid}$. In a judicial opinion from around the same time Frank found himself in agreement with the 'much abused [natural law] scholastics' on the binding force of precedents. Like the scholastics, Frank thought that reaching just outcomes required giving less respect to stare decisis and following precedents 'only when shown to be reasonable'. Aero Plug Co. Inc. v. B. G. Corp. (1942) I30 F.2d $290,298$.

${ }^{73}$ Jerome Frank, Law and the Modern Mind (New York: Brentano's, 1930) 292 (rhetorically asking if Roscoe Pound's endorsement of the view that eternal principles of natural law 'were not merely discoverable, but which, generally speaking, the jurists had discovered' was akin to 'a small boy with a grown-up vocabulary talking of an ideal father').

${ }^{74}$ Purcell (n 3) 4I. 
is best understood as an effort to mollify his critics and to pledge his allegiance to truth, justice, and the American way. Indeed, many scholars have interpreted Frank's and other realists' writing in something like this way. ${ }^{75}$

There is a morsel of truth in this explanation. Frank himself acknowledged that the experience of confronting the Nazi regime made the recognition of certain basic human values particularly pressing. ${ }^{76}$ But the charge that Frank fundamentally changed his views does not hold up under scrutiny, for it ignores both the extent to which Frank's deeper philosophical commitments remained consistent over this time period and the extent to which his understanding of natural law flowed from those commitments.

In particular, from his earlier writings to his latest ones, Frank was a philosophical pragmatist who assessed metaphysical concepts and theories-whether about the nature of the world, of the person, or of law-by how well their practical consequences served human needs and purposes. ${ }^{77}$ Frank combined this background philosophical view with a conviction that the most important human purpose in the political or moral sphere was to improve society overall, and that a judge's most important purpose when deciding cases was to ensure that justice is done in the individual case. This combination of philosophical outlook and substantive moral convictions about human purposes help explain the apparent contradictions noted above. For Frank, a properly sceptical attitude, which sees all knowledge as partial, ought to stimulate, rather than dampen, efforts to achieve reform and justice.

In the moral and political sphere, Frank embraced the quintessentially American idea that the future could be better than the past, together with the more controversial idea that law and government are an important means for achieving that goal. ${ }^{78}$ In his view, in order to make good on that possibility, the American people had to recognize that they had control over their own destiny and the freedom to choose wisely. And that meant rejecting the doctrine of scientific determinism. 'The world's future', he wrote, 'depends on human purposes, not on fate'. While some things are inevitable, he explained, others are not, so that ' $[\mathrm{w}] \mathrm{e}$ must reject the suggestion that we are

${ }^{75}$ See note I 2 .

${ }^{76}$ Frank (n 58) 294 (explaining and endorsing the view that natural law has become all the more important to recognize "now that we have been shocked by the Nazi assault into a realization of the worth of our basic ideals').

${ }^{77}$ See, e.g., ibid, r69 ('What criterion should one use in choosing between the competing assumptions of causality and acausality, neither of which can be "scientifically proved"? The criterion of their respective consequences.'). The argument supporting this pragmatist or 'humanist' interpretation of Frank's early work is developed further in Charles L. Barzun, 'Jerome Frank and the Modern Mind' (2010) 58 Buffalo Law Review I I 2 7, I $137-38$.

${ }^{78}$ See Jerome Frank, 'The New Sin', Saturday Review of Literature (22 December 1945) 3, 28; Frank (n $5^{8)} 3^{8-39}$. 
but molecules in a wave of the future. We must assert our faith in the power of free men to preserve a civilization in which freedom will seem to have been inevitablebecause free men have effectively willed that it should persist'. ${ }^{79}$ And for Frank, rejecting determinism meant welcoming the inherent unpredictability of life. Frank thought we ought to embrace 'the Renaissance belief in the reality of chance, a belief which the orthodox religion of science regards with horror' ${ }^{80}$

These quotations all come from Fate and Freedom, but there are important continuities and similarities between his earlier and later works. Frank's almost obsessive concern with the need to come to grips with deep epistemic uncertainty pervades his first book, Law and the Modern Mind.$^{81}$ Frank was primarily concerned there with attacking the demand for legal certainty, which he thought reflected childlike longings for security and comfort. But he found the same immature impulse driving what was, in his view, an equally quixotic effort to uncover causal laws governing the universe. ${ }^{82}$ 'Science, wisely considered is no substitute for the all-wise, all-powerful father', Frank insisted. 'The fact of change and chance must be bravely faced'. 83

We can now see more clearly why Frank both embraced many of the substantive moral and political values associated with natural law but resisted the label itself. On the one hand, he recognized that the core principles of a Thomistic natural law were invaluable as ideals and guides for action. ${ }^{84}$ They were sound if vague first principles and for a pragmatist like Frank, that fact was sufficient to justify belief their existence. ${ }^{85}$ But he resisted the idea that these principles closed any inquiry and that any particular application of those principles was permanently carved into nature itself because that view needlessly limited man's capacity to improve social and political life. That is why Frank was so concerned with showing how moralistic notions of natural law were, as a historical matter, bound up with the view that physical laws causally determined everything in nature, including human behaviour. By appealing to 'laws

${ }^{79} \mathrm{Ibid}, \mathrm{I} 7$.

${ }^{80} \mathrm{Ibid}$, I 38 . Compare this to Llewellyn's views in text accompanying note 25 above.

${ }^{81}$ Frank (n 73) 98 (emphasizing the need to develop 'the spirit of the creative scientist, which yearns not for safety but risk, not for certainty but adventure, which thrives on experimentation, invention and novelty and not on nostalgia for the absolute'). See also Barzun (n 77) i I 58-7 I (characterizing Frank's notion of the 'scientific spirit' as type of moral and intellectual virtue).

${ }^{82}$ Frank (n 73) 287 (denying that the universe will ever be reducible to 'scientific laws').

${ }^{83} \mathrm{Ibid}$.

${ }^{84}$ Frank (n 58) I 27 (observing favourably that for seventeenth-century social philosophers 'the axioms of a desirable (and possible) well-ordered state, said to be founded upon a study of human nature, were then regarded as "oughts," or norms, or standards, not as inescapable laws with which men could not help complying').

${ }^{85}$ Ibid, I69 (endorsing the logic of William James's 'faith ladder' according to which one reasons from the possibility of some view of the world being true, to the 'fitness' of it being true, to the conclusion that it 'shall be true'). 
of nature' both the normative and the causal versions of natural law had the consequence of limiting the possibilities for, and motivation to achieve, human freedom. ${ }^{86}$

In this way, Frank's scepticism served as a source not of despair but of faith, both in man's dignity and in social progress. If we can only gain knowledge of the world through our (limited, partial) human perceptual and cognitive faculties, then we can never know with certainty what the natural world is really like or how it operates. This means we need not accept the stultifying and depressing assumption that all human behaviour has been causally predetermined. Instead, since believing in free will, human dignity, and the core, eternal principles of natural law helps us bring about a more just and humane world, we are justified in holding such metaphysical and moral commitments. ${ }^{87}$ At the same time, remaining humble about our ability to discern what those general principles of natural law require in any particular set of circumstances should make us pause before advocating policies on the assumption that 'nature' requires them. 'Less cocksure about what we know and can know', Frank explained, 'we can be more sure that our choices will be real, not illusions'. ${ }^{88}$

We can see the same kind of dynamic at work in Frank's discussion of legal decision-making, where once again he uses scepticism to motivate and justify the pursuit of justice. In his early work the logic of Frank's argument is as follows: It is impossible to be certain about how judges will decide cases, either by looking to the relevant legal rules (as traditional jurists had argued) or by using the methods of social science (as other realists had argued). ${ }^{89}$ The reason is that a judge's idiosyncratic (and hence unpredictable) biases and prejudices often determine how he finds facts-for example, which witnesses he will believe and which he will not-thereby making it nearly impossible to predict how the legal rules will apply to future cases, even when those rules are clear. ${ }^{90}$ Thus, there is little point in judges trying to decide cases in such a way as to develop rules for future cases. ${ }^{91}$ Instead, Frank argued, such legal uncertain-

${ }^{86} \mathrm{Ibid}$, I 29 (criticizing those who believe that 'the power of the universe is on their side-that nature itself will compel men to accept the kind of social order which these Inevitabilists deem desirable').

${ }^{87} \mathrm{Ibid}$, I69 ("If the chance "axiom," with its "free will" conclusion, aids in promoting the human ideals we cherish, we have the right—still remaining thoroughly "rational”-

${ }^{88} \mathrm{Ibid}$, at 336 .

${ }^{89}$ Frank (n 73) I04-06. See also ibid, 362 ('the more accurate description of the judicial process will serve to show that efforts to procure such predictability (via anthropology, economics, sociology, statistics, or otherwise) are doomed to failure').

${ }^{90} \mathrm{Ibid}$, i I 6 ("No one can know in advance what a judge will believe to the "facts" of a case'). Frank could say that despite not doubting the existence of rules. In fact, in his preface to the I 949 edition of Law and the Modern Mind Frank treated as 'absurd' the suggestion that he 'sneered at legal rules' or 'considered them unreal or useless'. See Frank (n I I) xxvii.

${ }^{91} \mathrm{Ibid}$, I 55 ('Present problems should be worked out with reference to present events. We cannot rule the future. We can only imagine it in terms of the present. And the only way to do that is as thoroughly as possible to know the present'). 
ty should encourage judges to focus on the one thing that they can know and can control, namely how the legal materials ought to apply to the parties to the present case. For in Frank's view, the rules were simply instruments whose purpose was to serve justice to the parties in the case, so they should be interpreted accordingly. ${ }^{92}$

Frank was thus hardly sceptical about the possibility of securing genuinely just outcomes in individual cases. He merely thought that to pursue justice judges had to treat legal rules flexibly and attend primarily to the particular facts of the case. 'The judge, at his best, is an arbitrator', Frank insisted, 'a "sound man" who strives to do justice to the parties by exercising a wise discretion with reference to the peculiar circumstances of the case. ${ }^{93}$ His task, according to Frank, was to do 'equity' in the Aristotelian sense. ${ }^{94}$ Indeed, Frank's only criticism of Aristotle was that he treated equity as distinct from, and even contrary to, 'law', whereas Frank insisted that the two were 'so thoroughly intermingled that it is impossible to divide them' ${ }^{95}$

In this way, we can see a position that bears important similarities to his later views. He thought that values were more than mere prejudice and that judges should rely on them to reach just outcomes based on the particular circumstances of the case. ${ }^{96}$ What distinguished Frank's approach from more traditional views of natural law, however, was that for Frank, the key to securing just outcomes in adjudication lay not in properly deducing conclusions from the rules, nor in rigorously searching through of the case law. It required instead that judges attempt to overcome their own biases and prejudices through a process of introspection and self-analysis in the hope that doing so would enable them to discern in a less distorted way the relevant moral (and legal) considerations. ${ }^{97}$

Though Frank held on to all this throughout his life, one can identify a shift in his views from this highly personalist views of his earlier works toward greater respect for

${ }^{92}$ Frank (n 73) I67 ('We want judges who, thus viewing and employing all rules as fictions, will appreciate that, as rules are fictions "intended for the sake of justice," it is not to be endured that they shall work injustice in any particular case, and must be moulded in furtherance of those equitable objects to promote which they were designed') (emphasis in original).

${ }^{93} \mathrm{Ibid}$, 57 (emphasis in original).

${ }^{94}$ Ibid.

95 Ibid, I4I.

${ }^{96} \mathrm{Ibid}$, I 34 (suggesting that a 'deeper sense' of uniformity in case outcomes is likely to result to the extent that judges are 'the more enlightened, the more quick to detect and hold their own prejudices, the more alive to the fact that rules and precedents are not their masters but merely agencies to be utilized in the interest of doing justice'); ibid, r68 (quoting approvingly Morris Cohen's statement that there can be 'a scientific character to questions as to what the law ought to be').

${ }^{97} \mathrm{Ibid}$, I 47 (arguing that properly individualized, just adjudication requires judges to understand the law as 'a portion of the science of human nature' and emphasizing that that requires them to 'come to grips with the human nature operative in themselves' in order that they may become 'aware of [their] own prejudices, biases, antipathies, and the like'). 
the values held by the people. We identified a similar shift toward this view in Llewellyn's work, although they drew on different intellectual sources in reaching this view. Frank contrasted Plato's conception of natural law with Aristotle's. Plato's version of natural law was eternal and unchanging; Aristotle, by contrast, 'saw unconquerable unruliness, spontaneous chance and change, as part of reality, [and therefore] his notion of "natural law" was not likely to be that of an "absolute standard," permanent and unchanging, ${ }^{98}$ Frank drew an explicit link between Plato's conception of natural law and his totalitarianism and his 'contempt for democracy', and between Aristotle's openness to chance and his support for 'the loose texture of democracy'. ${ }^{99}$ In Frank's thinking a central reason for democracy is its recognition that certainty is an illusion and that those who claim to the right to rule because they have all the answers must be resisted. This is how Frank tied an epistemological thesis to political theory. ${ }^{100}$

Frank drew a similar connection between metaphysics and legal theory in a judicial opinion touching on the question of judicial impartiality. To be impartial judges need not, indeed cannot, become devoid of values, he said. This level of disinterestedness is only available to the dead. To the living, appeal to values is necessary and desirable. But which values? Frank mentioned, once again, the possibility of 'universal values' acknowledged by 'those devoted to "natural law" philosophy', but stated that these values are 'few and highly general' and 'their applications vary with time, place and circumstance'. ${ }^{101}$ In a manner not dissimilar to Llewellyn, he argued that what determines their content and application in particular circumstances were the values of the community:

[E]very human society has a multitude of established attitudes, unquestioned postulates. Cosmically, they may seem parochial prejudices, but many of them represent the community's most cherished values and ideals. Such social pre-conceptions, the "value judgments" which members of any given society take for granted and use as the unspoken axioms of thinking, find their way into that society's legal system, become what has been termed "the valuation system of the law." The judge in our society owes a duty to act in accordance with those basic predilections inhering in our legal

${ }^{98}$ Frank (n 60) I I 29; of Frank (n 69) 234-35; Frank (n 58) 295. For our purposes, it matters little whether this is a plausible reading of Aristotle. Interestingly, around the time a rather similar conception of natural law 'whose practical application will change as current notions of society change' was presented as the unacknowledged basis of legal realist Thurman Arnold's work. See Edward H. Levi, 'The Natural Law, Precedent, and Thurman Arnold' (I938) 24 Virginia Law Review 587, 6 I I-I 2.

${ }^{99}$ Frank (n 60) I I $27-28$.

${ }^{100}$ In seeing this connection, Frank was typical of his time. See Purcell (n 3) 205 (observing that for many intellectuals in the postwar period 'only social theories that recognized all truths, including ethical truths, as tentative, changing, and uncertain could support and justify democratic self-government').

${ }^{101}$ In re f.P. Linahan, Inc. (1943) I 38 F.2d 650, 652 note 6. 
system (although, of course, he has the right, at times, to urge that some of them be modified or abandoned). ${ }^{102}$

The values that underlie the law may be indefensible from the perspective of the cosmos, but that does not make them less real, and-in a democracy-less binding on the judge. Frank recognized that this was no panacea. He openly admitted that even in a particular period there is never perfect uniformity of opinion among all people ${ }^{103}$ which meant that uncertainty, in both law and fact-finding could not be eradicated. But just like in his earlier, more individualistic, perspective, Frank argued that these values should not be hidden or ignored. That was the kind of pragmatic constraint that was appropriate for an open, democratic society.

This view about how judges ought to go about resolving disputes was related for Frank to his views about the nature of law, and to the extent that we can find in them similarities to contemporary position, here too his views reveal clear continuity and seem to fit contemporary natural law theory (or at least versions of anti-positivism) much more than legal positivism. In Law and the Modern Mind Frank dismissed the positivist thesis about the limits of law: "what Pound calls law and what he calls nonlegal cannot be separated. They are so thoroughly intermingled that it is impossible to divide them'. ${ }^{104}$ Some fifteen years later, in discussing 'the relation of the natural law thesis to judicial activities' Frank states, in a manner that would not be out of place in Fuller: "Thus the ideal is constantly becoming the positive" and "in the evolution of the common law system the opposition between positive and natural law is constantly overcome"'. ${ }^{105}$

\section{Conclusion: The Philosophy of Reconstructing the Past}

'We are all realists now', as the saying goes, but what does that mean? 'We', after all, hold very different views on almost every topic that bears on realist themes: law, morality, society, politics, and the relationships among them. If, despite all our differences, we are all realists now, this must mean one of two things. Either the realism

${ }^{102} \mathrm{Ibid}, 652$ (footnotes omitted).

${ }^{103}$ See Ibid, 652 note 8; Perkins v. Endicott Fohnson Corp, I 28 F.2d 208, 2 I 7 note 25.

${ }^{104}$ Frank (n 73) I4I.

105 Frank (n 69) 234, quoting Friedrich Kessler, 'Natural Law, Justice and Democracy-Some Reflections on Three Types of Thinking about Law and Justice' (I944) i9 Tulane Law Review 32, 57; cf Lon L. Fuller, 'Reason and Fiat in Case Law' (I946) 59 Harvard Law Review 376, 379-80. Elsewhere, Frank characterized Fuller's natural law position as follows: that 'ideals of justice should be an acknowledged vital component in the thinking of judges when deciding cases.' Frank's did not think there was anything wrong with it, except that it was exceptional: 'today most American judges frankly and consciously think in that fashion-endeavoring, within the limits allowed by statues and well-settled precedents, to make their decisions conform to their ideals of justice'. Frank (n 58) 296. 
that we all share is so thin and banal that no-one could possibly object to it, or we mean by 'legal realism' utterly different things. With regard to some things, it may well be that we are all realists because the realists ideas are indeed rather banal and incontestable; although if that is the case, the realists would have little claim to being the seminal figures they are often held up to be. ${ }^{106}$ Thus, it seems more likely that scholars are drawing different lessons from the realists based on their own interests, values, and purposes.

Nor do we claim to be any different in this regard. No doubt we too are reading Llewellyn and Frank (and 'legal realism' more generally) through the lens of our interests, values, and purposes. And indeed, that recognition may itself one of the core messages both Frank and Llewellyn considered part of their legal realism. Nevertheless, while recognizing the historical embeddedness of all efforts to theorize about law (or any other social or political phenomenon), two points are worth mentioning. First, in our goal of reconstructing the thought of Frank and Llewellyn, we have above all sought to interpret what these thinkers said on their own terms, rather than simply assume that we can understand them by placing them within a particular historical context or political movement.

Second, our own interpretation of realism cannot be explained as merely the product of our historical moment, because in fact it cuts against the grain of the most popular interpretations of realism today. Legal realism is now back in vogue, even spawning a modern reincarnation known as 'new legal realism', in part because there has been renewed interest and confidence in bringing the social sciences to bear on legal issues. ${ }^{107}$ Thus, these days scholars-even those critical of the 'empirical turn'typically treat legal realism as largely an effort to convert law and legal scholarship in a more social scientific direction. Morton Horwitz, for example, has criticized ' $t$ ] he social science methodology that Llewellyn sought to represent... as the essence of Realism'. ${ }^{108}$ But although many of the legal realists certainly did see real possibilities in a more social-scientific orientation in legal scholarship, Llewellyn and Frank were in fact among the least enthusiastic about such an approach. In their different ways, they put much greater focus on law as part of the humanities, as an 'art' or a 'craft'. This may be yet another reason why they felt more comfortable with the label of natural law than some of their realist contemporaries.

106 This is, in a sentence, Brian Tamanaha's central claim in Beyond the Formalist-Realist Divide: The Role of Politics in Fudging (Princeton: Princeton University Press, 2010). We think that claim is likely too strong, but we cannot explore this question here.

${ }^{107}$ See, for example, the symposium on 'New Legal Realism' [2005] Wisconsin Law Review 335.

108 Morton J. Horwitz, The Transformation of American Law I 870-1960: The Crisis of Legal Orthodoxy (Cambridge: Harvard University Press, I992) 2 Io. 